\section{Growth Effects of Cross-border Mergers and Acquisitions in European Transition Countries}

\author{
Jelena Zvezdanović Lobanova \\ Centre for Economic Research, Institute of Social Sciences, Serbia \\ jzvezdanovic@idn.org.rs
}

\section{Davorin Kračun}

University of Maribor, Faculty of Economics and Business, Slovenia

davorin.kracun@um.si

\section{Alenka Kavkler}

University of Maribor, Faculty of Economics and Business, Slovenia alenka.kavkler@um.si

\begin{abstract}
This paper deals with the economic effect of cross-border mergers and acquisitions on GDP per capita in European transition countries for the 20002014 period. Our analysis shows that cross-border mergers and acquisitions have a negative effect on GDP per capita in the current period, whereas their lagged level positively impacts output performance. We found that transition countries characterized by a higher quality of institutional setting have achieved a positive impact on GDP per capita.
\end{abstract}

Key words: cross-border mergers and acquisitions; institutions; GDP per capita; transition countries

\section{Introduction}

During the 1990s, the contribution of cross-border mergers and acquisitions (C-B M\&As) to the production growth was much higher than in the case of greenfield investments (especially in transition countries). Their importance relies on the fact that they lead to crucial institutional and organizational changes within and across industries and regions as these transactions generate a large reallocation of resources, especially in the short run (Ferraz \& Hamaguchi, 2002, p. 383). Foreign direct investment (FDI) inflows have played a crucial role in strengthening the private sector and removing structural and macroeconomic imbalances, which are common to many transition countries (UNCTAD, 2003).

After the collapse of the administrative and planning system, post-socialist countries did not have sufficient financial resources to implement a costly innovative model of technological modernization, so they focused their attention on largescale FDI mobilization. They created conditions for attracting multinationals and the growth of C-B M\&A activity as the dominant mode of foreign entry. In order to improve investment attractiveness, these countries used special incentives, such as customs and tax exemptions or direct investment incentives for foreign investors,
ORIGINAL SCIENTIFIC PAPER

RECEIVED: JUNE 2016

REVISED: OCTOBER 2016

ACCEPTED: OCTOBER 2016

DOI: 10.1515/ngoe-2016-0019

UDK: $339.727 .22: 330.12$

JEL: E22; F21; F23

Citation: Zvezdanović Lobanova, J., Kračun, D., \& Kavkler, A. (2016). Growth Effects of Cross-border Mergers and Acquisitions in European Transition Countries. Naše gospodarstvo/Our Economy, 62(4), 3-11. DOI: 10.1515/ ngoe-2016-0019

\section{NG OE}

NAŠE GOSPODARSTVO OUR ECONOMY

vol. 62 No.4 2016

pp. 3-11 
such as the establishment of customs-free zones and industrial parks (UNCTAD, 2003). By opening their economies to foreign trade and investment, transition countries allowed the unhindered entry of multinational companies in order to overcome an obsolete production structure. Consequently, FDI inflows started to grow in several countries that succeeded in the process of market liberalization and privatization (particularly in the Czech Republic, Hungary, and Poland). The pattern and impact of C-B deals largely depended upon the legal and institutional environments in the host and home countries (Rossi \& Volpin, 2004). Their economic effects varied significantly across transition countries in line with the development of institutional arrangements and structural economic transformation.

Central and Eastern European countries that became candidates for EU membership had to accomplish the various institutional requirements, primarily the Copenhagen economic accession criteria. Aiming to fulfil EU institutional criteria, some transition countries succeeded in improving the quality of institutional setting by fostering institution building or changing legal and institutional framework. The integration with the EU played a role in establishing the external anchor for institutional changes, and the prospect of membership was a powerful magnet for the transition process (Roland, 2004, p. 57).

The aim of this paper is to investigate the economic effects of C-B M\&As on GDP per capita in 22 European transition countries $^{1}$ from 2000 to 2014 by applying dynamic panel data approach. We seek to demonstrate that current and lagged levels of C-B M\&As have a positive impact on macroeconomic performance in European transition countries. We also conduct the research in order to show that transition countries characterized by a higher quality of institutional setting achieve a positive impact on GDP per capita.

This study makes several contributions to the literature. We did not succeed in finding empirical studies dealing with the impact of C-B M\&As on economic growth in transition countries. Therefore, our empirical research contributes to the debate on the economic effects of capital flows by analysing the dynamic nature of this form of FDI and its influence on GDP per capita. In addition, we argue that, in order to accelerate the economic and social development of the countries in transition, it is crucially important to build institutions by creating new ones or improving the quality of existing institutions. Our paper is organized as follows. We first give a brief overview of recent literature on growth

\footnotetext{
${ }_{1}$ Countries included in the sample: Albania, Armenia, Belarus, Bosnia and Herzegovina, Bulgaria, Croatia, the Czech Republic, Estonia, Georgia, Hungary, Latvia, Lithuania, Macedonia, Moldova, Montenegro, Poland, Romania, Russia, Serbia, Slovakia, Slovenia, and Ukraine.
}

effects of FDI inflows in transition countries. We then discuss the data and research methodology, followed by our empirical findings and concluding remarks.

\section{Literature Review}

The empirical studies on the FDI as a determinant of economic growth are quite substantial, but they have not yielded consensual results. Melnyk, Kubatko, and Pysarenko (2014) examined the growth effects of FDI in 26 transition countries between 1998 and 2010, performing a fixed-effects panel data analysis. The authors demonstrated that well-developed institutional and financial sectors represented a crucial impetus for GDP growth and FDI inflows' attraction in former Comecon (the Council for Mutual Economic Assistance) transition and developing economies. Their results are in line with the findings of Silajdzic and Mehic (2016), who argued that FDI exerted a positive impact on economic growth in 10 Central and Eastern European countries from 2000 to 2011. Their findings demonstrated that FDI tends to have a larger impact on economic growth in host countries with sufficient absorptive capacity.

Mehic, Silajdzic, and Babic-Hodovic (2013) also found a positive and statistically significant effect of FDI on economic growth in the sample including seven South-eastern European countries from 1998 to 2007. Using the PraisWinsten regression model with panel-corrected standard errors, the authors showed that FDI is one of the crucial catalysts of economic growth in this group of countries compared to the contribution of domestic capital formation to output performance.

Hudea and Stancu (2012) investigated the relationship between FDI and economic growth for seven Eastern European countries from 1999 to 2009. By applying different panel estimations, panel co-integration, and causality analyses, the authors found that FDI has a direct and positive impact on GDP in the short and long run. This type of capital flow represents an opportunity for transition countries to reduce their technological gap compared to advanced countries. The authors also pointed out that a bi-directional causal relationship exists between GDP and FDI. Another interesting finding relates to the fact that FDI cannot contribute to the income growth in countries that did not implement a comprehensive process of privatization.

Botrić, Bačić, and Slijepčević (2015) evaluated the underlying relationship among FDI, trade, and growth in the group of post-transition countries denoted as late reformers. Their findings suggested that the FDI-led growth hypothesis is valid as a positive long-run relationship exists between 
growth and FDI for these countries. Elkomy, Ingham, and Read (2016) examined the role of transition status and the level of political development in determining the effects of FDI on growth for a panel of 61 transition and developing countries between 1989 and 2013. The authors found that the economic effects of FDI on output performance were insignificant in 10 transition countries whereas FDI played a pivotal role in the economic growth and development of non-transition countries.

Yet FDI can be a source of negative economic effects because its impact depends on the underlying economic and political factors in the host transition countries. Mencinger (2003) examined the relationship between FDI and economic growth with the help of panel data for eight EU candidate countries between 1994 and 2001. He found that transition countries did not achieve the growth-enhancing effect of FDI because it mainly took the form of acquisitions related to massive and often politically motivated privatizations. According to him, FDI in transition countries mainly led to the creation of a monopoly in the host market, which destroyed and/or enabled the entry of potential domestic enterprises. Consequently, total investment does not increase by the amount of FDI, which is directly reflected in economic growth and real convergence of the candidate countries with the EU.

Mencinger's (2003) findings are consistent with the conclusions drawn by Curwin and Mahutga (2014), who examined the influence of FDI on economic growth for 25 transition countries from 1990 to 2010. They argued that an increase of FDI leads to an economic decline in the short and long term if the FDI penetration is implemented too quickly. They further demonstrated that domestic investment is more beneficial for economic growth compared to FDI as it is not accompanied by deleterious consequences at the macroeconomic level. According to their opinion, this negative FDI affecting economic growth could be explained by a weak institutional setting as a crucial mediator of the economic effects of FDI.

By applying the fixed effects dynamic panel estimation method, Sapienza (2010) found that the current FDI has a negative impact on economic performance while its lagged value has a significant and positive effect on economic growth in host countries. The author pointed out that spill-over effects from this type of capital flow in terms of know-how and technology need time to arise.

\section{Data and Research Methodology}

Our sample consisted of 22 European transition countries for the 2000-2014 period; this panel data set was strongly balanced. Data on C-B M\&As were taken from the United
Nation Conference on Trade and Development (UNCTAD) database. We expressed this variable as a percentage of GDP, like other authors. Data for our dependent variable-GDP per capita in current US\$-were taken from the World Bank. We calculated domestic investment as the difference between gross fixed capital formation and inward FDI (based on data from the World Bank). The source of governance indicators was database compiled by Kaufmann, Kraay, and Mastruzzi (2010). The data for governance balance were obtained from EBRD and Eurostat.

Initial conditions in transition countries are presented with the help of data on purchasing power parity income per capita in 1989, which came from an IMF (2000) publication (except for Serbia, Bosnia and Herzegovina, and Montenegro, whose data were based on the authors' calculations). By using GDP per capita in 1989, we considered the fact that the characteristics of economic and institutional development of these countries depend on different initial conditions at the beginning of their transition process. We provide the descriptive statistics in Table 1 and correlation coefficients in Table 2. According to the descriptive statistics, significant variations emerged between levels of economic development in transition countries. For example, the mean C-B M\&As share in GDP for the total sample is $0.78 \%$, with a standard deviation of 1.68 . We also found large variations in domestic investment and budget balance among transition countries. For instance, the domestic investment amounted to approximately $18 \%$ on average, far exceeding C-B M\&As as a percentage of GDP.

Table 1. Descriptive Statistics

\begin{tabular}{lccccc} 
Variable & $\begin{array}{c}\text { Obser- } \\
\text { vation }\end{array}$ & Mean & \multicolumn{3}{c}{$\begin{array}{c}\text { Standard } \\
\text { Deviation }\end{array}$} \\
\hline Log(GDP pc) & 330 & 8.5673 & 0.9215 & 5.8693 & 10.2220 \\
\hline C-B M\&As & 330 & 0.7799 & 1.6788 & -1.7933 & 13.2099 \\
\hline Budget & 327 & -2.7964 & -2.7964 & -15 & 8.4 \\
\hline Income & 220 & 8.5188 & 0.5230 & 7.2442 & 9.1269 \\
\hline DI & 327 & 18.4148 & 6.2387 & -15.2087 & 36.8126 \\
\hline
\end{tabular}

Source: Authors' research

Table 2. Correlation Matrix for GDP Per Capita Determinants

\begin{tabular}{lccccc}
$\#$ & Log(GDP pc) & C-B M\&As & Budget Income & DI \\
\hline Log(GDP pc) & 1.00 & & & & \\
\hline C-B M\&As & -0.03 & 1.00 & & & \\
\hline Budget & -0.13 & -0.05 & 1.00 & & \\
\hline Income & 0.49 & 0.01 & 0.09 & 1.00 & \\
\hline DI & 0.23 & -0.21 & -0.03 & 0.41 & 1.00 \\
\hline
\end{tabular}

Source: Authors' research 
We investigated the economic effects of C-B M\&As on GDP per capita in 22 European transition countries for the 20002014 period. We applied a dynamic panel data analysis to test the following hypotheses:

H1: C-B M\&As have a positive impact on GDP per capita in the year of the merger or acquisition in European transition countries.

H2: The positive economic effect of one-year lagged C-B M\&As on the host country's GDP per capita was also recorded one year after the merger or acquisition.

H3: Transition countries characterized by a higher quality of institutional setting have a positive impact on GDP per capita.

Following the previous empirical research (e.g., Efendić, Geoff, \& Adnett, 2014; Mehić et al., 2013; Sapienza, 2010), we estimated this form of panel model specification in order to test these hypotheses:

$$
\begin{aligned}
\log \left(\mathrm{GDPpc}_{\mathrm{it}}\right)= & \beta_{0}+\beta_{1} \log \left(\mathrm{GDPpc}_{\mathrm{it}-1}\right)+ \\
& +\beta_{2} \mathrm{C}-\mathrm{BM} \& \mathrm{As}_{\mathrm{it}}+\beta_{3} \mathrm{C}-\mathrm{BM} \mathrm{MAs}_{\mathrm{it}-1}+ \\
& +\beta_{4} \mathrm{INS}_{\mathrm{it}}+\beta_{5}{ }^{\mathrm{T}} \mathrm{CON}_{\mathrm{it}}+\varepsilon_{\mathrm{it}}
\end{aligned}
$$

where the subscript $i$ denotes $i^{\text {th }}$ country $(i=1 \ldots 22)$ and the subscript $t$ denotes the $t^{\text {th }}$ year $(t=1 \ldots 15)$, while $\beta_{0}$ to $\beta_{5}$ are regression coefficients. Transposed vector is denoted by $\mathrm{T}$ while $\varepsilon_{\text {it }}$ are the error terms. GDPpc it $_{\text {it }}$ the GDP per capita (in natural logarithm), $\mathrm{GDPpc}_{\mathrm{it}-1}$ is the lagged dependent variable, $\mathrm{C}-\mathrm{B} \mathrm{M} \& \mathrm{As}_{\mathrm{it}}$ represents C-B M\&As as a percentage of GDP, C-B M\&As it- $1_{\text {in }}$ is the lagged variable, $\mathrm{INS}_{\text {it }}$ is the institutional quality dummy variable equal to 1 when a chosen governance indicator is greater than its median, and $\mathrm{CON}_{\mathrm{it}}$ is a vector of control variables including:

- government balance (Budget ${ }_{i t}$ ),

- domestic investment as percentage of GDP (DI ${ }_{i t}$ ), and

- GDP per capita PPP in 1989 dollars (in natural logarithm) ( Income $_{\text {it }}$ ).

We expected all of the identified independent variables to have a positive impact on economic growth, with the exception of initial GDP per capita. We also estimated the C-B M\&As adjustment by including only their first lag, as the higher order lags proved to be insignificant.

Following previous empirical works (Morrissey \& Udomkerdmongkol, 2012), we included dummy variables for the overall institutional quality index and separate governance indicators in order to distinguish countries with a high and low quality institutional environment. As these dummy variables are highly correlated among each other, we included them separately in different regression equations (see Table 3) in order to avoid multicollinearity.

Based on the calculated percentile rank, dummy variables were assigned the value 1 if the transition country had a good institutional setting (value of overall institutional quality index or chosen governance indicator was above the median) and 0 otherwise. First, we calculated the overall institutional quality index with the help of the principal component analysis (PCA) method. This multivariate procedure summarized the six worldwide governance indicators (WGIs) — voice and accountability (VA), political stability and absence of violence (PSAV), government effectiveness (GE), regulatory quality (RQ), rule of law (RL), and control of corruption (CC) - into one factor. The value of each indicator ranged from -2.5 to 2.5 , with higher values indicating a better quality of institutional setting. The first principal component obtained from these indicators captured $86 \%$ of the variations in the original governance indicators. In addition, according to the Kaiser-Meyer-Olkin (KMO) measure of sampling adequacy (0.90), the data were suitable for PCA. ${ }^{2}$

In order to estimate the extent to which C-B M\&As influence GDP per capita, we applied a two-step system generalized method of moments (GMM) estimator (Blundell \& Bond, 1998) including the Windmeijer finite sample correction (Windmeijer, 2005). The usage of this estimation technique is preferred for panels with a small number of periods and a large number of observations, a linear functional relationship, a dynamic dependent variable (dependence on its own past values), and independent variables that are not strictly exogenous and fixed individual effects (Roodman, 2009). It takes into account the specificity of each observation unit and allows for heteroscedasticity and autocorrelation within the units, but not among them. According to Blundell, Bond, and Windmeijer (2000, p. 2), a system GMM is based on relatively mild restrictions on the initial condition process.

Compared to the difference GMM, the system GMM leads to the improvement of the precision and reduction of the finite sample bias by exploiting instruments available for the equations in levels (Blundell et al., 2000, p. 30). Its specificity is reflected in the fact that the instruments in levels remain good predictors for the endogenous variables in this model even when the series are highly persistent like institutions (Blundell \& Bond, 1998, p. 138). Moreover, the first difference transformation could remove the fixed country-specific effect, which might lead to misleading results. The use of the system GMM estimator also solves the problem of magnifying gaps arising from the difference GMM estimator, as pointed by Roodman (2009, p. 104). The system GMM

\footnotetext{
$\overline{2}$ These results can be provided by the authors, upon request.
} 
enabled us to capture the effects of lagged C-B M\&As on the current economic effects of C-B M\&As.

We applied the Hansen test to analyse the appropriateness of the model specification and validity of over-identifying restrictions. If the system is over-identified, a test statistic for the joint validity of the moment conditions (identifying restrictions) falls naturally out of the GMM framework (Roodman, 2009, p. 97). We strictly adhered to the rule that the number of instruments should be less than or equal to the number of groups (in contrast to Efendić et al., 2014; Morrissey \& Udomkerdmongkol, 2012). In addition, we provided the standard set of GMM diagnostics to allow us to assess the validity of our results. The presence of the serial correlation of residuals was tested in order to achieve consistent estimates of the parameters. Therefore, we checked for the second-order serial correlations of the differenced residuals. According to Arellano and Bond (1991), no second-order serial correlation should occur in the first-difference residuals.

In our panel model specification, the one-year lagged GDP per capita, C-B M\&As, and domestic investment were assumed to be endogenous variables instrumented with GMM-style instruments, while the others were considered exogenous. We used lags 2 to 4 of endogenous variables in order to alleviate the instrument proliferation problem. The collapse option was also used to reduce the size of the instrument matrix in order to obtain one instrument per variable instead of one instrument for each variable in each period.

For the estimation of the coefficient and the standard error of the long-run effects of C-B M\&As on GDP per capita, we considered the explanation given by Papke and Wooldridge (2005) and used the "nlcom" command in STATA 12. The long-term effect is the product of multiplying estimated coefficients by the long-run multiplier $\frac{1}{\left(1-\beta_{1}\right)}$, (where $\beta_{1}$ is the estimated coefficient of the lagged dependent variable).

All the estimations are performed using the xtabond2 program written by Roodman (2009).

\section{Empirical Results and Discussion}

Our estimates of the equations in Table 3 are largely consistent with the results achieved by the other authors. In terms of diagnostics, the results of the Hansen test showed that the chosen instrument set is exogenous, while the AR(2) test also indicated no problem of autocorrelation. The lagged level of GDP per capita had a positive and highly significant impact on the GDP per capita in the current period in all our specifications.
Column 1 shows that current C-B M\&As had a negative and statistically significant effect on GDP per capita, while their lagged level had a highly significant positive impact on output performance. The budget balance as a proxy of macroeconomic stability had a statistically significant positive impact on GDP per capita in all our regressions, indicating the importance of stabilization measures for output performance. Domestic investment had a positive regression coefficient in all our regressions, but its influence was insignificant. On the other hand, the impact of the initial GDP per capita was positive, but its $p$-value was not close to the conventional level of significance. Overall, the institutional quality dummy was also positive and significant at the 0.01 level, suggesting that transition countries characterized by a higher quality of institutional setting achieved a positive impact on GDP per capita.

In column 2, we replaced the overall institutional dummy with the CC, yielding a positive and highly significant coefficient for this variable. We also found that contemporaneous C-B M\&As had a negative sign but were insignificant, while their lagged level had a positive and statistically significant coefficient at the 0.01 level. In column 3 , we included the PSAV dummy, which had the expected positive sign but was not statistically significant. None of the control variables had statistically significant coefficients, with the exception of government balance and lagged GDP per capita, which had statistically significant coefficients in all columns. Column 4 shows that the coefficient of RL was positive and significant. The coefficients of current and lagged C-B M\&As had signs and significances as in the previous column. After including the VA in column 5, the coefficient of lagged C-B M\&As became significant at the 0.05 level. In columns 6 and 7, we included the RQ and GE, and the evidence suggests that these dummy variables exerted a positive and statistically significant impact on GDP per capita. We found that the significance of other variables was unaffected after including $\mathrm{VA}, \mathrm{RQ}$, and GE in equations.

The main results of our growth regression indicate that C-B M\&As had a negative effect (only significant in one column) on GDP per capita in the current period. In the year of the merger or acquisition, transition countries characterized by open capital accounts experienced an increase in economic instability. This form of FDI was related to the privatization of public assets, which usually caused layoffs and decreases in production immediately after the merger or acquisition. Privatization, as one of the strategies for the restructuring of state-owned enterprises in these countries, was implemented in conditions of underdeveloped financial and capital market, low quality of institutional setting, and poor macroeconomic conditions. As privatization aims to improve management quality and raise employment capacity in an inefficient economic system, it is not surprising that this 
type of enterprise restructuring leads to an increase in unemployment in a short period of time. We conclude that local authorities' concerns about the decrease of production capacity, employee layoffs, and business restructuring in the frames of outsourcing process are fully justified in the short run. Therefore, our findings do not confirm H1 that C-B M\&As have a positive economic effect on GDP per capita in the host transition countries in the period of study.

On the other hand, the lagged value of C-B M\&As showed a significant positive impact on GDP per capita in five of the seven columns, which leads to the conclusion that this form of FDI needs time to produce positive economic effects. Our results provided evidence in favour of accepting H2: The positive economic effect of C-B M\&As on GDP per capita was recorded one year after the merger or acquisition. An increase of GDP per capita might arise due to technology spill-over effects (in the case of proper innovation absorption capacity), development of employees' knowledge and skills, as well as strategic partnerships between domestic and foreign companies. In addition, the operation of large foreign investors encourages other international companies from their supply chain to open production facilities in transition countries. Our finding is consistent with the study of Sapienza (2010), who found that contemporaneous FDI has a negative and insignificant impact on economic growth whereas its lagged level shows a positive effect.

From the long-term perspective, C-B M\&As do not positively contribute to an increase in GDP per capita as their coefficient is negative and highly significant (-0.425). This longterm coefficient estimate was calculated using the "nlcom" command in STATA 12 (the results are reported in Table 4). Our explanation for such an influence relies on the fact that foreign investors tend to reduce the number of employees and production in the long run or even leave transition countries after they exploit preferences of the local market. However, our long-term estimates should be considered with a certain amount of scepticism as they were based on several assumptions that do not correspond to economic reality (stability of the whole system and ceteris paribus factors).

Table 3. Economic Effect of C-B M\&As on GDP Per Capita with Respect to Governance Variables Dummies

\begin{tabular}{|c|c|c|c|c|c|c|c|}
\hline \multirow{3}{*}{ Variables } & \multirow{2}{*}{$\begin{array}{c}\text { Overall } \\
\text { institutional } \\
\text { quality index }\end{array}$} & \multicolumn{6}{|c|}{ Governance indicators } \\
\hline & & $\mathrm{CC}$ & PSAV & $\mathrm{RL}$ & VA & $\mathrm{RQ}$ & GE \\
\hline & 1 & 2 & 3 & 4 & 5 & 6 & 7 \\
\hline lngdppc(-1) & $\begin{array}{l}0.792^{* * *} \\
(0.024)\end{array}$ & $\begin{array}{l}0.778^{* * *} \\
(0.044)\end{array}$ & $\begin{array}{l}0.814^{* * *} \\
(0.051)\end{array}$ & $\begin{array}{l}0.790^{* * *} \\
(0.035)\end{array}$ & $\begin{array}{l}0.828^{* * *} \\
(0.032)\end{array}$ & $\begin{array}{l}0.794^{* * *} \\
(0.064)\end{array}$ & $\begin{array}{l}0.805^{* * *} \\
(0.033)\end{array}$ \\
\hline M\&As & $\begin{array}{l}-0.088^{* *} \\
(0.035)\end{array}$ & $\begin{array}{l}-0.102 \\
(0.064)\end{array}$ & $\begin{array}{l}-0.082 \\
(0.094)\end{array}$ & $\begin{array}{l}-0.080 \\
(0.056)\end{array}$ & $\begin{array}{l}-0.078 \\
(0.060)\end{array}$ & $\begin{array}{l}-0.087 \\
(0.104)\end{array}$ & $\begin{array}{l}-0.079 \\
(0.073)\end{array}$ \\
\hline$M \& A s(-1)$ & $\begin{array}{l}0.024^{* * *} \\
(0.006)\end{array}$ & $\begin{array}{l}0.023^{* * *} \\
(0.005)\end{array}$ & $\begin{array}{c}0.020 \\
(0.013)\end{array}$ & $\begin{array}{c}0.024 \\
(0.008) \\
\end{array}$ & $\begin{array}{l}0.025^{* *} \\
(0.009)\end{array}$ & $\begin{array}{c}0.025^{*} \\
(0.012) \\
\end{array}$ & $\begin{array}{c}0.025^{*} \\
(0.012) \\
\end{array}$ \\
\hline Budget & $\begin{array}{l}0.019^{* * *} \\
(0.006)\end{array}$ & $\begin{array}{l}0.016^{* * *} \\
(0.005)\end{array}$ & $\begin{array}{l}0.016^{* *} \\
(0.007)\end{array}$ & $\begin{array}{l}0.018^{* * *} \\
(0.005)\end{array}$ & $\begin{array}{l}0.019^{* *} \\
(0.006)\end{array}$ & $\begin{array}{l}0.018^{* *} \\
(0.007)\end{array}$ & $\begin{array}{c}0.018^{* *} \\
(0.007) \\
\end{array}$ \\
\hline INS & $\begin{array}{l}0.244^{* * *} \\
(0.057)\end{array}$ & $\begin{array}{l}0.208^{* * *} \\
(0.061)\end{array}$ & $\begin{array}{c}0.144 \\
(0.097)\end{array}$ & $\begin{array}{l}0.217^{* * *} \\
(0.073)\end{array}$ & $\begin{array}{l}0.197^{* * *} \\
(0.061)\end{array}$ & $\begin{array}{l}0.193^{* *} \\
(0.079)\end{array}$ & $\begin{array}{l}0.171^{* * *} \\
(0.048)\end{array}$ \\
\hline Income & $\begin{array}{c}0.009 \\
(0.067) \\
\end{array}$ & $\begin{array}{c}0.017 \\
(0.072) \\
\end{array}$ & $\begin{array}{c}0.053 \\
(0.062) \\
\end{array}$ & $\begin{array}{c}0.048 \\
(0.060) \\
\end{array}$ & $\begin{array}{l}-0.009 \\
(0.142) \\
\end{array}$ & $\begin{array}{l}-0.010 \\
(0.155) \\
\end{array}$ & $\begin{array}{c}0.008 \\
(0.072) \\
\end{array}$ \\
\hline $\mathrm{DI}$ & $\begin{array}{c}0.005 \\
(0.009) \\
\end{array}$ & $\begin{array}{c}0.009 \\
(0.012) \\
\end{array}$ & $\begin{array}{c}0.003 \\
(0.015) \\
\end{array}$ & $\begin{array}{c}0.002 \\
(0.011) \\
\end{array}$ & $\begin{array}{c}0.009 \\
(0.019) \\
\end{array}$ & $\begin{array}{c}0.011 \\
(0.027) \\
\end{array}$ & $\begin{array}{c}0.009 \\
(0.015) \\
\end{array}$ \\
\hline Time effect & yes & yes & yes & yes & yes & yes & yes \\
\hline No. of Obs. & 280 & 283 & 280 & 283 & 284 & 281 & 281 \\
\hline No. of groups & 22 & 22 & 22 & 22 & 22 & 22 & 22 \\
\hline No. of instruments & 16 & 16 & 16 & 16 & 16 & 16 & 16 \\
\hline $\begin{array}{l}\text { Hansen test } \\
(p \text { value })\end{array}$ & 0.679 & 0.770 & 0.124 & 0.664 & 0.265 & 0.249 & 0.288 \\
\hline $\operatorname{AR}(2)$ ( $p$ value $)$ & 0.658 & 0.726 & 0.446 & 0.709 & 0.416 & 0.633 & 0.571 \\
\hline
\end{tabular}

Source: Authors' calculations

Note: The variable INS is defined differently in each model (column). It is an institutional quality dummy based on either an overall institutional quality index or one of the governance indicators (CC, PSAV, RL, VA, RQ, GE). Standard errors are in parentheses. ***, **, and $*$ indicate significance at the $1 \%, 5 \%$, and $10 \%$ levels, respectively. 
Table 4. Long-run Effect of Change in C-B M\&As on GDP Per Capita

\begin{tabular}{ccccccc} 
Variable & Coefficient & Standard Errors & $\mathrm{t}$ & $\mathrm{P}>|\mathrm{t}|$ & & [95\% Conf. Interval] \\
\hline C-B M\&As & -0.425 & 0.149 & -2.85 & 0.009 & -0.734 & -0.116 \\
\hline
\end{tabular}

Source: Author's calculations

Note: The coefficient is calculated using the "nlcom" command in Stata 12. The results are based on column 1 from Table 3.

Table 5. Differences in GDP Per Capita and C-B M\&As as Percentage of GDP, with Respect to Quality of Institutional Setting in Given Countries, 2000-2014

\begin{tabular}{lcccccc} 
& \multicolumn{3}{c}{ Low governance countries } & \multicolumn{3}{c}{ High governance countries } \\
\cline { 2 - 7 }$\#$ & GDP per capita & C-B M\&As & $\begin{array}{c}\text { Institutional } \\
\text { quality }\end{array}$ & GDP per capita & C-B M\&As & $\begin{array}{c}\text { Institutional } \\
\text { quality }\end{array}$ \\
\hline Observations & 153 & 153 & 153 & 177 & 177 & 177 \\
\hline Mean & 3892.42 & 0.6374 & -1.2374 & 10671.19 & 0.9030 & 1.0696 \\
\hline $\begin{array}{l}\text { Standard } \\
\text { Deviation }\end{array}$ & 2733.40 & 1.2714 & 1.9853 & 6143.70 & 1.9595 & 1.6025 \\
\hline Minimum & 354.00 & -1.7933 & -8.0801 & 407.73 & -0.8305 & -7.2794 \\
\hline Maximum & 14487.28 & 6.8755 & 1.2051 & 27501.82 & 13.2099 & 3.2121 \\
\hline
\end{tabular}

Source: Authors’ calculations

The coefficients' sign of the dummy variables for higher governance quality is in line with our predictions. All measures for institutional quality were positive and significant (with the exception of PSAV in regression 3), thereby confirming H3 - that transition countries characterized with a higher quality of institutional setting (above the median) ${ }^{3}$ achieved a positive impact on GDP per capita. The coefficient of PSAV was positive but insignificant, suggesting that once a country achieves a certain level of political stability, further progress made in this area produces a negligible impact on GDP per capita.

Transition countries seeking to join the EU and OECD achieved better results in the improvement of their institutional environment. They were encouraged to adopt Western market economic and legal systems and accomplish all necessary requirements for integration. These requirements were very similar to the conditions for the successful transition period. The accession of eight former socialist economies during the "wave" of the fifth enlargement in 2004 and further EU enlargement in 2007 (Bulgaria and Romania) and 2013 (Croatia) meant that candidate countries accepted the acquis in its existing form and succeeded in institutional harmonization, but to different extents. After joining the EU, the given countries enjoyed the benefits of membership, which positively reflected on their rate of economic growth and export expansion.

\footnotetext{
3 Bulgaria, Croatia, the Czech Republic, Hungary, Latvia, Lithuania, Estonia, Poland, Romania, Slovenia, and Slovakia.
}

Table 5 also provides support for our prediction that institutional setting improvement corresponded not only with higher volumes of this type of FDI, but also gave impetus for GDP per capita performance in transition countries. The table shows the differences in the level of GDP per capita and C-B M\&As (as a percentage of GDP) among the chosen transition countries according to the quality of their institutional settings. As a criterion for grouping countries, we used the overall institutional quality index calculated by the PCA analysis. Those transition countries whose overall institutional quality index was above the median are denoted as countries with a better quality of institutional setting. We found that the level of GDP per capita and C-B M\&As as a percentage of GDP were higher in those transition countries characterized by better institutional quality.

\section{Conclusion}

This paper investigated the economic effect of C-B M\&As on GDP per capita in 22 European transition countries from 2000 to 2014. The main finding of our empirical study is that the impact of this type of FDI is positive and statistically significant only one year after the merger or acquisition. We argued that C-B M\&As need time to produce positive economic effects that arise due to technology spill-over effects, the development of employees' knowledge and skills, and strategic partnerships between domestic and foreign companies. From a long-term perspective, their 
impact on GDP per capita is negative and highly statistically significant. We believe that foreign companies' activities may be guided by short-term interests, which lead to the crowding-out of domestic companies from the local market. We determined that all measures for institutional quality are positive and significant (with the exception of political stability and absence of violence), thereby confirming our hypothesis that transition countries characterized by a higher quality of institutional setting (above the median) achieved a positive impact on economic growth.

\section{References}

Arellano, M., \& Bond, S. (1991). Some tests of specification for panel data: Monte Carlo evidence and an application to employment equations. Review of Economic Studies, 58(2), 277-97. https://doi.org/10.2307/2297968

Blundell, R., \& Bond, S. (1998). Initial conditions and moment restrictions in dynamic panel data models. Journal of Econometrics, 87(1), 115-143. https://doi.org/10.1016/S0304-4076(98)00009-8

Blundell, R., Bond, S., \& Windmeijer, F. (2000). Estimation in dynamic panel data models: improving on the performance of the standard GMM estimator, IFS Working Paper (W00/12), The Institute for Fiscal Studies.

Botrić, V., Bačić, K., \& Slijepčević, S. (2015). FDI, trade and growth in the "late reformers" post transition. Paper presented at the International Finance and Banking Conference FIBA 2015.

Curwin, K. D., \& Mahutga, M. C. (2014). Foreign direct investment and economic growth: New evidence from post-socialist transition countries. Social Forces, 92(3), 1159-1187. https://doi.org/10.1093/sf/sot128

Efendić, A., Geoff, P., \& Adnett, N. (2010). Institutions and economic performance: System GMM modelling of institutional effects in transition. Retrieved from http://riinvestinstitute.org/pdf/Efendic_et_al.pdf

Elkomy, S., Ingham, H., \& Read, R. (2016). Economic and political determinants of the effects of FDI on growth in transition and developing countries. Thunderbird International Business Review, 58(4), 347-362. https://doi.org/10.1002/tie.21785

Ferraz, J. C., \& Hamaguchi, N. (2002). Introduction: M\&A and privatization in developing countries. The Developing Economies, 40(4), 383-399. https://doi.org/10.1111/j.1746-1049.2002.tb00920.x

Hudea, O. S., \& Stancu, S. (2012). Foreign direct investments, technology transfer and economic growth: A panel approach. Romanian Journal of Economic Forecasting, 15(2), 85-102.

IMF (2000). World economic outlook: Focus on transition economies, Washington, DC: International Monetary Fund.

Kaufmann, D., Kraay, A., \& Mastruzzi, M. (2010). The worldwide governance indicators methodology and analytical issues. World Bank Policy Research Working Paper No. 5430. Washington, DC: World Bank.

Mehic, E., Silajdzic, S., \& Babic-Hodovic, V. (2013). The impact of FDI on economic growth: Some evidence from Southeast Europe. Emerging Markets Finance \& Trade, 49(1), 5-20. https://doi.org/10.2753/REE1540-496X4901S101

Melnyk, L., Kubatko, O., \& Pysarenko, S. (2014). The impact of foreign direct investment on economic growth: case of post communism transition economies. Problems and Perspectives in Management, 12(1), 17-24.

Mencinger, J. (2003). Does foreign direct investment always enhance economic growth? Kyklos, 56(4), 491-508. https://doi.org/10.1046/j.0023-5962.2003.00235.x

Morrissey, O., \& Udomkerdmongkol, M. (2012). Governance, private investment and foreign direct investment in developing countries. World Development, 40(3), 437-445. https://doi.org/10.1016/j.worlddev.2011.07.004

Papke, L. E., \& Wooldridge, J. M. (2005). A computational trick for delta-method standard errors. Economics Letters, 86, $413-417$. https://doi.org/10.1016/j.econlet.2004.07.022

Roland, G. (2004). After enlargement: Institutional achievements and prospects in the new member states. In C. Detken, V. Gaspar, \& G. Noblet (Eds.), The new EU member states-Convergence and stability (pp. 35-58). Frankfurt: European Central Bank.

Roodman, D. (2009). How to do xtabond2: An introduction to "difference" and "system" GMM in Stata. Stata Journal, 9(1), 86-136.

Rossi, S., \& Volpin, P. (2004). Cross-country determinants of mergers and acquisition. Journal of Financial Economics, 74, $277-304$. https://doi.org/10.1016/j.jineco.2003.10.001

Sapienza, E. (2010). Foreign direct investment and growth in Central, Eastern and Southern Europe. Investigación Económica, $271,99-138$.

Silajdzic, S., \& Mehic, E. (2016). Absorptive capabilities, FDI, and economic growth in transition economies. Emerging Markets Finance \& Trade, 52(4), 904-922. https://doi.org/10.1080/1540496X.2015.1056000

UNCTAD. (2003). World investment report 2003: FDI policies for development: National and international perspectives. New York and Geneva: United Nations Conference on Trade and Development.

Windmeijer, F. (2005). A finite sample correction for the variance of linear efficient two-step GMM estimators. Journal of Econometrics, 126(1), 25-51. https://doi.org/10.1016/j.jeconom.2004.02.005 


\section{Authors}

Jelena Zvezdanović Lobanova is a doctoral student of economic and business sciences at the Faculty of Economics and Business, University of Maribor. She earned her master's degree in economic policy and development at the Faculty of Economics, University of Belgrade. She currently works as a research assistant at the Centre for Economic Research, Institute of Social Sciences in Belgrade. Named the Best Graduate Economist at the University of Niš in 2007-2008 for faculties in socio-humanistic sciences, Lobanova received the University Silver Sign on the Day of the University. Her research interests include international capital flows, cross-border mergers and acquisitions, and quality of institutional setting.

Davorin Kračun, Ph.D., is a professor of economics at the Faculty of Economics and Business, University of Maribor. He received his Ph.D. in economics from the University of Zagreb, Croatia. He was the vice-dean of the School of Business and Economics and the academic chairman. Today he is the chair of the Department for Political Economy and the acting dean of the faculty. In the government of the Republic of Slovenia, professor Kračun was the Minister of Foreign Affairs, Deputy Prime Minister and Minister of Economic Relations and Development, and Minister of Planning. He served as Slovenia's ambassador to the United States. He was also the chairman of the Supervisory Boards of Nova Kreditna Banka Maribor, the corporation Terme Maribor and the chairman of the Supervisory Board of Pošta Slovenije. His scientific bibliography consists of more than 500 subjects.

Alenka Kavkler is an associate professor of quantitative methods in business science at the Faculty of Economics and Business, University of Maribor. She received her M.Sc. in mathematics from the University of Ljubljana and her Ph.D. from the Vienna University of Technology. Her research is mainly focused on nonlinear econometric models, especially smooth transition regression models. She is currently the head of the Institute of Operations Research at the Faculty of Economics and Business.

\section{Vpliv čezmejnih združitev in prevzemov na gospodarsko rast v evropskih tranzicijskih državah}

\section{Izvleček}

V članku se ukvarjamo z ekonomskim učinkom čezmejnih združitev in prevzemov na BDP na prebivalca $v$ evropskih tranzicijskih državah v obdobju med letoma 2000 in 2014. Naši empirični rezultati kažejo, da imajo čezmejne združitve in prevzemi negativen učinek na BDP na prebivalca v tem obdobju, vpliv odložene spremenljivke pa je pozitiven. Ugotavljamo, da so tranzicijske države, ki izkazujejo višjo kakovost institucionalnega okolja, uresničile pozitiven vpliv na BDP na prebivalca.

Ključne besede: čezmejne združitve in prevzemi, institucije, BDP na prebivalca, tranzicijske države 